
(1)

\title{
30 YEARS OF THE MINERALOCORTICOID RECEPTOR
}

Mineralocorticoid receptor and $\mathbf{N a C l}$ transport mechanisms in the renal distal nephron

\author{
Shigeru Shibata1,2 \\ 1Division of Nephrology, Department of Internal Medicine, Teikyo University School of Medicine, Tokyo, Japan \\ 2Division of Clinical Epigenetics, Research Center for Advanced Science and Technology, University of Tokyo, \\ Tokyo, Japan
}

Correspondence should be addressed to S Shibata Email shigeru.shibata@med. teikyo-u.ac.jp

\begin{abstract}
A key role of aldosterone and mineralocorticoid receptor is to regulate fluid volume and $\mathrm{K}^{+}$homeostasis in the body by acting on the renal distal nephron. Global responses of the kidney to elevated aldosterone levels are determined by the coordinate action of different constituent tubule cells, including principal cells, intercalated cells and distal convoluted tubule cells. Recent studies on genetic mutations causing aldosterone overproduction have identified the molecules involved in aldosterone biosynthesis in the adrenal gland, and there is also increasing evidence for mechanisms and signaling pathways regulating the balance between renal $\mathrm{NaCl}$ reabsorption and $\mathrm{K}^{+}$secretion, the two major effects of aldosterone. In particular, recent studies have demonstrated that mineralocorticoid receptor in intercalated cells is selectively regulated by phosphorylation, which prevents ligand binding and activation. Moreover, the ubiquitin ligase complex composed of Kelch-like 3 and Cullin 3 acts downstream of angiotensin II and plasma $\mathrm{K}^{+}$alterations, regulating $\mathrm{Na}-\mathrm{Cl}$ cotransporter independently of aldosterone in distal convoluted tubule cells. These and other effects are integrated to produce appropriate kidney responses in a high-aldosterone state, and are implicated in fluid and electrolyte disorders in humans. This review summarizes the current knowledge on mechanisms modulating mineralocorticoid receptor and its downstream effectors in the distal nephron.
\end{abstract}

\author{
Key Words \\ - angiotensin \\ - plasma K \\ - KLHL3 \\ - ubiquitin proteasome \\ system \\ - phosphorylation
}

Journal of Endocrinology (2017) 234, T35-T47

\section{Introduction}

The main function of the kidney is to maintain constant fluid volume and composition by altering the functioning of various cells lining the nephron. Changes in electrolyte balance are transmitted to individual cells through multiple signaling pathways, inducing appropriate responses to physiological perturbations and altered intake. The steroid hormone aldosterone is produced in zona glomerulosa cells of the adrenal cortex and it regulates $\mathrm{Na}^{+}, \mathrm{K}^{+}$and $\mathrm{Cl}^{-}$ balance in the body mainly by acting on the distal part of the renal nephron (which normally includes distal convoluted tubules (DCTs), connecting tubules and collecting duct). Although $\mathrm{NaCl}$ reabsorbed in the distal segment represents only a fraction of that handled by the nephron, fine tuning occurs in this segment, which determines total body salt

This paper is part of a thematic review section on 30 Years of the Mineralocorticoid Receptor. The guest editors for this section were John Funder and

Maria Christina Zennarp.loaded from Bioscientifica.com at 04/26/2023 10:26:08AM 
and water content. Cells of the distal nephron also play important roles in controlling extracellular $\mathrm{K}^{+}$levels, and dysregulation of transporters and channels in these segments is a major cause of altered blood pressure and plasma $\mathrm{K}^{+}$levels (Lifton et al. 2001, Boyden et al. 2012).

Aldosterone is produced in two distinct physiological states, hypovolemia (intravascular volume depletion) and hyperkalemia. In the former, activation of the reninangiotensin system induces angiotensin II (AngII) type 1 receptor signaling in glomerulosa cells, stimulating aldosterone biosynthesis via $\mathrm{Ca}^{2+}$ signaling (Spat \& Hunyady 2004, Boulkroun et al. 2015). On the other hand, hyperkalemia stimulates aldosterone production by directly depolarizing the cells and activating voltage-gated $\mathrm{Ca}^{2+}$ channels (Spat \& Hunyady 2004, Boulkroun et al. 2015). Aldosterone, in turn, increases mineralocorticoid receptor (MR) transcriptional activity in the distal nephron and regulates the activity of electrolyte transport mediators, which maximizes either $\mathrm{NaCl}$ reabsorption or $\mathrm{K}^{+}$secretion depending on the physiological context. Recent genetic studies of familial electrolyte imbalances as well as biochemical analyses of renal electrolyte flux regulators and upstream signaling pathways have provided insights into the molecular mechanisms that modulate the action of aldosterone in the distal nephron. In this review, the current knowledge on mechanisms that regulate electrolyte flux mediators in cells lining the distal nephron is summarized (i.e., principal cells, intercalated cells, and DCT cells (Fig. 1)). Accumulating evidence indicates that both MR-dependent and -independent factors are involved. In addition, how these mechanisms are integrated to produce appropriate responses upon physiological perturbations and under pathological conditions is also discussed.

\section{Role of principal cells in $\mathrm{NaCl}$ and $\mathrm{K}^{+}$regulation}

Principal cells express epithelial $\mathrm{Na}^{+}$channel (ENaC), a heterotrimeric protein composed of $\alpha, \beta$ and $\gamma$ subunits (Pearce et al. 2015). While most $\mathrm{Na}^{+}$transport occurring in the renal tubules is coupled to the transport of other anions or cations (e.g., $\mathrm{Na}^{+}-\mathrm{H}^{+}$exchanger 3 or $\mathrm{Na}^{+}$-glucose cotransporters in the proximal tubules, $\mathrm{Na}^{+}-\mathrm{K}^{+}-2 \mathrm{Cl}^{-}$ cotransporter 2 in the thick ascending limb and $\mathrm{Na}-\mathrm{Cl}$ cotransporter (NCC) in the DCT), only $\mathrm{Na}^{+}$ions are transported through ENaC. This electrogenic $\mathrm{Na}^{+}$ reabsorption generates a lumen-negative potential, and establishes an electrochemical gradient that drives $\mathrm{Cl}^{-}$ and $\mathrm{K}^{+}$transport. Loss-of-function mutations in this channel not only affect $\mathrm{Na}^{+}$reabsorption but also perturb $\mathrm{Cl}^{-}$and $\mathrm{K}^{+}$transport (Lifton et al. 2001). Conversely, gainof-function mutations in this channel cause high blood pressure and hypokalemia (Table 1) (Shimkets et al. 1994, Staub et al. 1996, Kamynina \& Staub 2002). As discussed later, the most important regulator of $\mathrm{ENaC}$ is aldosterone.

Apical $\mathrm{K}^{+}$secretion in principal cells is a critical determinant of the amount of $\mathrm{K}^{+}$excreted in urine and it is regulated by renal outer medullary $\mathrm{K}^{+}$(ROMK) channel. Like other inwardly rectifying $\mathrm{K}^{+}$channels, ROMK forms a tetramer and is highly selective for $\mathrm{K}^{+}$over $\mathrm{Na}^{+}$and other ions. The ROMK gene contains several exons that produce alternatively spliced transcripts, and principal cells of the cortical collecting duct express ROMK1 and

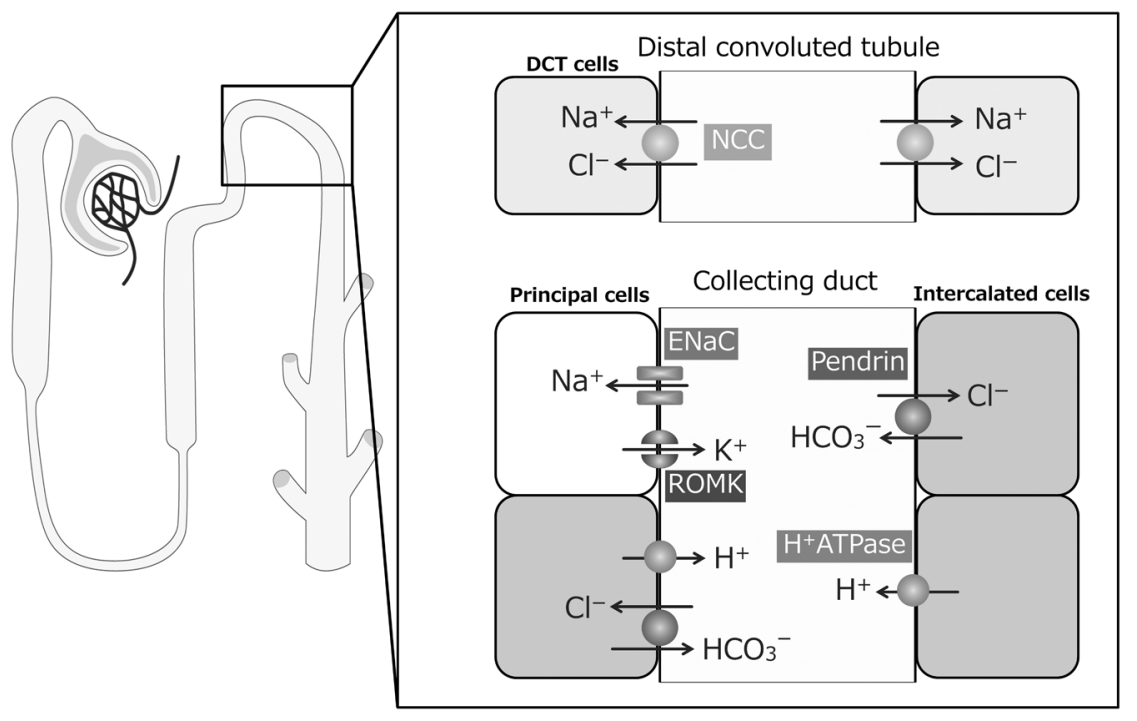

\section{Figure 1}

Cells comprising the renal distal nephron. Distal convoluted tubule (DCT) cells express thiazidesensitive $\mathrm{Na}-\mathrm{Cl}$ cotransporter (NCC) at the apical membrane. Principal cells of the collecting duct express epithelial $\mathrm{Na}^{+} \mathrm{Channel}(\mathrm{ENaC})$ and renal outer medullary $\mathrm{K}^{+}$channel (ROMK) at the apical membrane. Intercalated cells are divided into three types; $\alpha$-intercalated cells express $\mathrm{H}^{+}-$ATPase, whereas $\beta$-intercalated cells express $\mathrm{Cl}-/ \mathrm{HCO}_{3}-$ exchanger pendrin at the apical membrane. Non- $\alpha$, non- $\beta$ intercalated cells are characterized by the expression of both pendrin and $\mathrm{H}^{+}-$ATPase at the apical membrane.
๑) 2017 Society for Endocrinology Printed in Great Britain
Published by Bioscientifica Ltd. 
Table 1 Human conditions related to dysregulation of MR or downstream effectors in the distal nephron.*

\section{Disease or disorder}

Pseudohypoaldosteronism type 1 (PHAI)

Hypertension exacerbated by pregnancy

Apparent mineralocorticoid excess (AME)

Liddle syndrome

Gitelman syndrome

Pendred syndrome

Pseudohypoaldosteronism type 2 (PHAll or FHHt)

Licorice-induced hypertension

CNI-induced hypertension

Clinical characteristics
Neonatal salt wasting, hyperkalemia,
metabolic acidosis
Early onset hypertension, markedly
accelerated in pregnancy
Early onset hypertension,
hypokalemia, metabolic alkalosis
Early onset hypertension and
hypokalemic alkalosis
Hypokalemia, metabolic alkalosis,
mild hypotension
Hearing loss and thyroid
abnormality; potential for
hypokalemia, metabolic alkalosis
and fluid loss
Hypertension, hyperkalemia and
metabolic acidosis
Hypertension, hypokalemia,
metabolic alkalosis
Hypertension associated with the use
of CNls such as tacrolimus and
cyclosporine

Genetic cause or suggested mechanism

MR mutation leading to activation by steroids lacking 21-hydorxyl (e.g., progesterone)

MR activation by cortisol due to mutation in $11 \beta \mathrm{HSD} 2$

Mutation in $\mathrm{ENaC} \beta$ or $\gamma$ resulting in reduced clearance by Nedd4-2

Loss-of-function mutation in NCC

Loss-of-function mutation in pendrin

NCC overactivity due to mutation in KLHL3/CUL3 or WNK

Inhibition of $11 \beta \mathrm{HSD} 2$ by glycerrhetinic acid

NCC activation via WNK-SPAK pathway of CNIs such
cyclosporine

*Disorders resulting from the increased circulating mineralocorticoids are not included in the table.

$11 \beta H S D 2$, 11ß-hydroxysteroid dehydrogenase 2; CNI, calcineurin inhibitor; CUL3, cullin-3; ENaC, epithelial Na channel; FHHt, familial hyperkalemic hypertension; KLHL3, Kelch-like 3; MR, mineralocorticoid receptor; NCC, Na-Cl cotransporter; SPAK, STE20/SPS1-related kinase; WNK, with-no-lysine.

ROMK2 (Hebert et al. 2005). ROMK is sensitive to changes in $\mathrm{pH}$, and is inhibited by the decrease in intracellular pH levels (Hebert et al. 2005). Several other upstream regulators are known to regulate ROMK such as serum and glucocorticoid-induced kinase 1 (Sgk1) and Src family protein tyrosine kinase. SGK1 facilitates ROMK activity by phosphorylating S44 (Yoo et al. 2003). On the other hand, Src phosphorylates ROMK at Y337, which facilitates ROMK internalization (Lin et al. 2004). ROMK is also known to be inhibited by serine threonine kinase WNK4 (With-No-Lysine 4) via kinase-independent mechanism (Kahle et al. 2003), which acts in concert with Sgk1 and Src (Lin et al. 2015).

\section{MR signaling in principal cells of the collecting duct}

MR is abundantly expressed in principal cells of the collecting duct and the role of aldosterone and MR in these cells has been extensively characterized (Pearce et al. 2015). The most important downstream effector of MR signaling in these cells is the amiloride-sensitive epithelial $\mathrm{Na}^{+}$channel (ENaC). Principal cells highly express

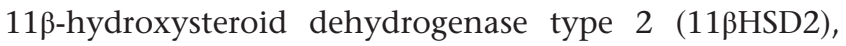
which catalyzes the conversion of cortisol to inactive cortisone and allows selective MR activation by aldosterone (Funder et al. 1988). In apparent mineralocorticoid excess (AME), decreased 11ßHSD2 activity due to a hereditary defect or pharmacological inhibition causes cortisol accumulation in these cells, resulting in MR activation by cortisol. The most common cause of secondary AME is the intake of licorice, whose active ingredient glycyrrhizinic acid inhibits $11 \beta \mathrm{HSD} 2$ activity (Table 1 ).

Once activated, MR controls $\mathrm{ENaC}$ function at multiple levels mainly by regulating the Ser/Thr kinase Sgk1 and the ubiquitin ligase Nedd4-2 (Pearce et al. 2015). Firstly, MR controls the stability of $\mathrm{ENaC}$ at the plasma membrane. Sgk1 transcription is rapidly induced by aldosterone, and is then activated by phosphatidylinositide 3-kinase and mammalian target of rapamycin complex 2 (Lang \& Pearce 2016). Phosphorylated active Sgk1 in turn phosphorylates Nedd4-2, a homologous to the E6-AP carboxyl terminus (HECT) domain-containing E3 ubiquitin ligase that binds the C-terminal PY motif of $\mathrm{ENaC}$ to induce its degradation. Sgk1 phosphorylation of Nedd4-2 triggers the binding of 14-3-3 proteins, thereby inhibiting the association between ENaC and Nedd4-2 (Bhalla et al. 2005, Lang \& Pearce 2016). This prevents ubiquitination, internalization and degradation, resulting in increased plasma membrane levels of ENaC. In Liddle syndrome, nonsense or 
frameshift mutations in SCNN1B (encoding $\mathrm{ENaC} \beta$ ) and SCNN1G (encoding ENaCy) eliminate the C-terminal PY motif, abrogating the Nedd4-2-ENaC association similar to biological effects of Nedd4-2 phosphorylation by Sgk1 (Shimkets et al. 1994, Staub et al. 1996, Kamynina \& Staub 2002). Besides these mechanisms, ENaC stability at the plasma membrane is controlled by the aldosteroneinduced proteins Glucocorticoid-induced leucine-zipper protein 1 and the connector enhancer of kinase suppressor of Ras isoform 3, both of which form the multiprotein $\mathrm{ENaC}$ regulatory complex (Pearce et al. 2015).

Secondly, aldosterone regulates $\mathrm{ENaC}$ gene expression. The promoter of $S C N N 1 A$ (encoding $\mathrm{ENaC} \alpha$ ) contains a glucocorticoid-responsive element, with gene transcription induced by aldosterone (Mick et al. 2001). Interestingly, this effect appears to be partly mediated by Sgk1. Acute lymphocytic leukemia 1-fused gene from chromosome 9 (Af9), a putative transcription factor, binds to the histone H3 Lys-79 methyltransferase Dot1a to regulate the histone methylation of the SCNN1A promoter. Sgk1 phosphorylates Af9 and prevents the Dot1a-AF9 interaction, leading to histone hypomethylation and increased SCNN1A transcription (Zhang et al. 2007).

Thirdly, aldosterone increases $\mathrm{ENaC}$ open probability via the regulation of serine proteases. Among the three subunits of ENaC, $\alpha$ and $\gamma$ subunits are activated by cleavage of the inhibitory domain in the extracellular loop, which is mediated by cell-surface or soluble extracellular serine proteases such as prostasin, plasmin and kallikrein (Vallet et al. 1997, Narikiyo et al. 2002, Svenningsen et al . 2015). For example, prostasin promotes the cleavage of the $\mathrm{ENaC} \gamma$ protein inhibitory domain (Narikiyo et al. 2002). Importantly, urinary prostasin levels are increased in subjects with primary aldosteronism, and is reduced after adrenalectomy (Narikiyo et al. 2002), suggesting that hyperaldosteronism promotes $\mathrm{ENaC}$ activity via protease induction and cleavage of the inhibitory domain. Urine from patients with nephrotic syndrome shows increased plasmin levels and serine protease activity, which contributes to increased $\mathrm{ENaC}$ by directly cleaving $\mathrm{ENaC} \gamma$ (Svenningsen et al. 2009).

$\mathrm{Na}^{+}$reabsorbed through ENaC is transported to the extracellular fluid via $\mathrm{Na}^{+} / \mathrm{K}^{+}$-ATPase, a heteromeric protein composed of $\alpha, \beta$ and $\gamma$ subunits. The activity of $\mathrm{Na}^{+} / \mathrm{K}^{+}$-ATPase in principal cells is increased in response to aldosterone, and several lines of evidence suggest that both direct and indirect effects are involved. Studies have shown that the induction of $\mathrm{Na}^{+} / \mathrm{K}^{+}$-ATPase activity by aldosterone was inhibited by amiloride
(Hayhurst \& O'Neil 1988). Consistent with these findings, a recent study reported that $\mathrm{ENaC}$ induction increased $\mathrm{Na}^{+} / \mathrm{K}^{+}$-ATPase levels and activity in mouse cortical collecting duct cells (Wang et al. 2014). This effect was regulated at the post-transcriptional levels through the inhibition of p38 kinase-mediated endocytosis of $\mathrm{Na}^{+} / \mathrm{K}^{+}$-ATPase (Wang et al. 2014). Besides these mechanisms, aldosterone can increase the transcription of ATP1A1 and ATP1B1 subunits (Tsuchiya et al. 1996, Setiawan et al. 2002, Alvarez de la Rosa et al. 2006). Several studies have also suggested that Sgk1 is involved in the regulation of $\mathrm{Na}^{+} / \mathrm{K}^{+}$-ATPase (Verrey et al. 2003a,b). Thus, the available evidence indicates that $\mathrm{Na}^{+} / \mathrm{K}^{+}$-ATPase activity is coordinately regulated by aldosterone and by the $\mathrm{Na}^{+}$entry through ENaC.

\section{Role of intercalated cells in fluid and electrolyte homeostasis}

While principal cells constitute the majority of cells lining the collecting duct, distinct cell types are also present in this segment, which are grouped together and known as intercalated cells. These are further divided into $\alpha-, \beta-$, and non- $\alpha$, non- $\beta$ intercalated cells according to the subcellular localization of $\mathrm{H}^{+}-\mathrm{ATPase}$ and $\mathrm{Cl}^{-} / \mathrm{HCO}_{3}{ }^{-}$ exchangers. $\alpha$-Intercalated cells express $\mathrm{H}^{+}$-ATPase and the $\mathrm{Cl}^{-} / \mathrm{HCO}_{3}{ }^{-}$exchanger AE1 at the apical and basolateral membranes, respectively. In contrast, $\beta$-intercalated cells express the $\mathrm{Cl}^{-} / \mathrm{HCO}_{3}-$ exchanger pendrin and $\mathrm{H}^{+}$-ATPase at the apical and basolateral membranes, respectively. Non- $\alpha$, non- $\beta$ intercalated cells are characterized by the expression of both pendrin and $\mathrm{H}^{+}$-ATPase at the apical membrane.

Intercalated cells have long been recognized for their role in acid/base homeostasis; however, there is accumulating evidence to suggest that they also control extracellular fluid volume and $\mathrm{K}^{+}$homeostasis. As mentioned earlier, the activation of $\mathrm{ENaC}$ in principal cells creates an electrochemical gradient that promotes either $\mathrm{K}^{+}$secretion or $\mathrm{Cl}^{-}$reabsorption in the collecting duct (Welling 2013, Pearce et al. 2015). $\mathrm{K}^{+}$is excreted via ROMK in principal cells, whereas $\mathrm{Cl}^{-}$ions are transported either para- or transcellularly (Hou et al. 2013, Wall \& Weinstein 2013). In the former process, $\mathrm{Cl}^{-}$permeability of the cell-cell junction is determined by several claudins (Hou et al. 2013), whereas the latter process is primarily mediated by pendrin in $\beta$-intercalated cells (Royaux et al. 2001, Wall et al. 2004). Indeed, $\mathrm{Cl}^{-}$flux in the cortical collecting duct was abolished in mice lacking

Published by Bioscientifica Ltd. 
pendrin, which resulted in a blunted pressor response to mineralocorticoids (Wall et al. 2004). Moreover, mice lacking both pendrin and NCC showed severe volume depletion (Soleimani et al. 2012), demonstrating the compensatory role of these $\mathrm{Cl}^{-}$transporters. Conversely, pendrin overexpression induced salt-dependent hypertension (Jacques et al. 2013). These findings are also relevant to humans, because individuals with Pendred syndrome (who have loss-of-function mutations in SLC26A4 (encoding pendrin)) are extremely sensitive to thiazide diuretics (Pela et al. 2008). In addition, several reports have shown that the individuals with Pendred syndrome can potentially develop life-threatening hypokalemia associated with volume depletion and metabolic alkalosis (Kandasamy et al. 2011, SaneiMoghaddam et al. 2011), providing further evidence that pendrin indeed regulates electrolyte balance.

Studies have also suggested the role of $\mathrm{H}^{+}$-ATPase in intercalated cells in $\mathrm{NaCl}$ and $\mathrm{K}^{+}$homeostasis. Unlike in other cell types, the resting membrane potential of intercalated cells is determined by the activity of $\mathrm{H}^{+-}$ ATPase rather than that of $\mathrm{Na}^{+} / \mathrm{K}^{+}$-ATPase (Chambrey et al. 2013). The B1 subunit of $\mathrm{H}^{+}-\mathrm{ATPa}$ ise is selectively expressed in renal intercalated cells, and mutations in the gene encoding this protein (ATP6V1B1) cause metabolic acidosis and hypokalemia (Karet et al. 1999, Finberg et al. 2003). Although fluid status has not been extensively studied in humans, mice lacking B1 $\mathrm{H}^{+}$-ATPase showed a salt loss phenotype (Gueutin et al. 2013). Although the underlying mechanism is not entirely clear, $\mathrm{B} 1 \mathrm{H}^{+}$-ATPase regulates $\mathrm{ENaC}$ levels via prostaglandin $\mathrm{E} 2$ paracrine signaling (Gueutin et al. 2013). Other studies have shown that apical $\mathrm{H}^{+}$-ATPase activity provides a driving force for transcellular $\mathrm{Cl}^{-}$transport in the collecting duct (Pech et al. 2007).

Although the primary target of thiazide diuretics is NCC in DCTs, it is thought that $\mathrm{NaCl}$ transport mechanisms sensitive to thiazide also exist in the cortical collecting duct (Terada \& Knepper 1990). Since ENaC is not inhibited by thiazide, this mechanism was presumed to be independent of electrogenic $\mathrm{Na}^{+}$transport in principal cells. Subsequent studies have characterized the mechanism as one involving $\mathrm{Na}^{+}$-driven $\mathrm{Cl}^{-} / 2 \mathrm{HCO}_{3}{ }^{-}$ exchanger (NDCBE) in $\beta$-intercalated cells; it was proposed that parallel operation of this exchanger and pendrin results in electroneutral $\mathrm{NaCl}$ transport (Leviel et al. 2010). A recent follow-up study reported the physiological effects resulting from the loss of NDCBE. As the renal salt transport mechanism is highly redundant, the effects of NDCBE deletion are largely compensated by other $\mathrm{NaCl}$ transport mechanisms along the nephron (Sinning et al. 2016). Double knockout of NDCBE and NCC resulted in hypokalemia and signs of volume contraction, although the phenotype was milder than that of pendrin and NCC double-knockout mice. These data support the role of NDCBE but also indicate that fluid volume regulation through pendrin is not solely dependent on NDCBE.

\section{MR signaling in intercalated cells of the collecting duct}

As stated above, recent studies have shown that membrane transporters present in intercalated cells regulate blood pressure and electrolyte balance. Although the detailed biochemical pathways regulating their function are less well characterized than those of $\mathrm{ENaC}$ in principal cells, it is known that intercalated cells express MR (Ackermann et al. 2010, Izumi et al. 2011). In addition, aldosterone as well as other mineralocorticoids regulates intercalated cell function. Aldosterone stimulates acid secretion in $\alpha$-intercalated cells (Garg \& Narang 1988). Pendrin in $\beta$-intercalated cells is also induced by chronic infusion of aldosterone (Verlander et al. 2003). However, the effects of mineralocorticoids in these cells may not be apparent depending on the physiological context (Mohebbi et al. 2013), indicating that modulation of MR signaling is complex and involves mechanisms that are distinct from those in principal cells.

Besides circulating ligands, there is increasing evidence to suggest that the function of steroid and other nuclear receptors are modulated at the receptor level by multiple factors. In particular, post-translational modification significantly alters nuclear receptor function (Gaillard et al. 2006, Choi et al. 2010, Kino et al. 2010). Several studies have shown that $\mathrm{MR}$ is phosphorylated, which is mediated by kinases such as cyclin-dependent kinase 5 and mitogen-activated protein kinase (Alnemri et al. 1991, Galigniana 1998, Kino et al. 2010, Faresse et al. 2012). However, the significance of phosphorylation in the regulation of MR function was unclear. Using a phospho-proteomics approach (Rinehart et al. 2009), we identified 16 phosphorylation sites in full-length human MR (Shibata et al. 2013a). Phosphorylation at S843 (the only site in the ligand-binding domain) had the greatest functional effect in a luciferase reporter assay, and previous studies have reported that this site is responsible for the difference in ligand selectivity between glucocorticoid receptor and MR (Ortlund et al. 2007). The importance of S843 for MR function was also suggested by the

Published by Bioscientifica Ltd. 
observation that it is mutated (p.Ser843Pro) in subjects with pseudohypoaldosteronism type I (PHAI) (FernandesRosa et al. 2011). A binding assay using a MR ${ }^{\text {S843E }}$ phosphomimetic revealed that phosphorylation severely impaired aldosterone binding; accordingly, cell culture experiments demonstrated that phosphorylated MR is exclusively cytoplasmic in the presence of physiological concentrations of its ligand aldosterone.

In the kidney, MR phosphorylated at S843 (MR ${ }^{\text {s843-P) }}$ is almost exclusively localized in the cytoplasm of renal intercalated cells (Shibata et al. 2013a), and is not detected in principal or DCT cells. Of note, hypovolemia via AngII signaling and $\mathrm{K}^{+}$loading decreased and increased $\mathrm{MR}^{\mathrm{s} 843-\mathrm{P}}$ levels, respectively. The former was associated with an increased nuclear accumulation of MR in intercalated cells, consistent with the in vitro finding that MR ${ }^{\mathrm{S} 843-\mathrm{P}}$ regulates ligand binding and nuclear translocation. Moreover, in volume depletion, we found that dephosphorylation of $\mathrm{MR}^{\text {S843-P }}$ results in ligand-dependent increases in intercalated cell apical $\mathrm{H}^{+}$-ATPase and pendrin. Thus, the ligand-binding ability of MR is selectively regulated by phosphorylation in intercalated cells, which controls $\mathrm{Cl}^{-}$reabsorption mechanisms involving intercalated cells while minimizing changes in acid/base balance.

Interestingly, we recently found that these mechanisms also regulate plasma $\mathrm{K}^{+}$concentrations
(Xu et al. 2017). The decrease in plasma $\mathrm{K}^{+}$levels dephosphorylates $\mathrm{MR}^{\mathrm{s} 843-\mathrm{P}}$, which facilitates liganddependent MR activation and increases pendrin levels (Fig. 2). This mechanism promotes $\mathrm{Cl}^{-}$reabsorption but instead reduces $\mathrm{K}^{+}$secretion in the distal nephron. Indeed, genetic ablation of pendrin aggravates hypokalemia in aldosterone excess (Xu et al. 2017), demonstrating that intercalated cell $\mathrm{Cl}^{-}$flux through pendrin regulates not only blood pressure but also plasma $\mathrm{K}^{+}$levels. Thus, hypokalemia dephosphorylates $\mathrm{MR}^{\mathrm{s} 843-\mathrm{P}}$, which promotes MR activation and pendrin expression, counteracting the progression of hypokalemia but instead promoting hypertension. The proposed mechanism may also explain why individuals with Pendred syndrome have the potential to develop severe hypokalemia and show the impaired ability to reduce $\mathrm{K}^{+}$excretion in the face of reduced total body $\mathrm{K}^{+}$(Pela et al. 2008, Kandasamy et al. 2011, Sanei-Moghaddam et al. 2011).

$\mathrm{MR}^{\text {S843-P }}$ has been detected in the kidney but not in other tissues known to express MR, including brain, heart, colon and vasculature. However, considering the low expression levels of total MR in these organs relative to the renal tubules, it is still possible that $\mathrm{MR}^{\text {s843-P }}$ is expressed outside the kidney. Given that signaling crosstalk between MR and AT1R has been reported in vascular smooth muscle cells, a role in the cardiovascular system
Principal cells

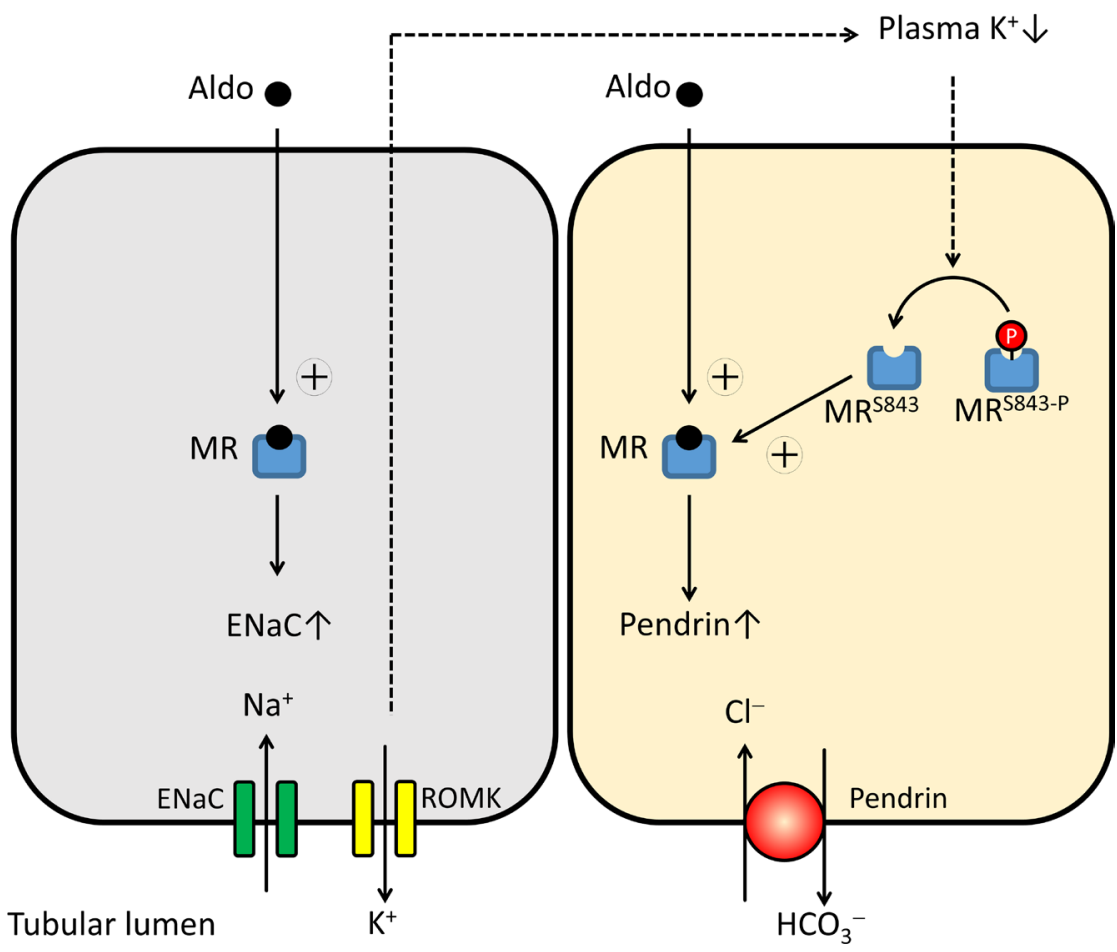

Figure 2

Regulation of MR in $\beta$-intercalated cells. In principal cells, aldosterone binds to MR and activates $\mathrm{ENaC}$, which drives $\mathrm{K}+$ secretion through apical $\mathrm{K}^{+}$channel ROMK. The resultant decrease in plasma $\mathrm{K}^{+}$levels causes $\mathrm{MR}^{\mathrm{s} 843-\mathrm{P}}$ dephosphorylation in $\beta$-intercalated cells, allowing aldosterone binding to MR in these cells and increasing pendrin at the plasma membrane. Reproduced, with permission, from Xu N, Hirohama D, Ishizawa K, Chang WX, Shimosawa T, Fujita T, Uchida S \& Shibata S (2017) Hypokalemia and pendrin induction by aldosterone. Hypertension [in press]. 
may be worth investigating. Studies on the role of cortisol in regulating MR in intercalated cells are also the areas of future investigation (Funder 2013).

\section{Mechanisms regulating NCC in DCT cells}

Thiazide-sensitive NCC regulates salt transport in DCTs, contributing to fluid volume homeostasis. The key regulatory mechanism of NCC was elucidated by genetic and biochemical analyses of PHAII pathogenesis. PHAII, also known as Gordon syndrome or familial hyperkalemic hypertension, is characterized by pathological NCC hyperactivity; hypertension and hyperkalemia in these patients can be reversed by thiazide treatment. Mutations in four genes are known to cause PHAII (Wilson et al. 2001, Boyden et al. 2012, Louis-Dit-Picard et al. 2012). Two of these encode the serine threonine kinases With-no-lysine (WNK) 1 and WNK4, whereas the other two genes encode Cullin 3 (CUL3) and Kelch-like 3 (KLHL3), both of which are components of a Really Interesting New Gene (RING) E3 ubiquitin ligase complex.

Kinase-active WNKs phosphorylate the downstream kinases STE20/SPS1-related proline-alanine-rich protein kinase (SPAK) and oxidative stress-responsive (OSR) 1 (Vitari et al. 2005), which in turn phosphorylate NCC at the $\mathrm{C}$ terminus and thereby activate the transporter. WNK1 has a $\mathrm{Cl}^{-}$binding pocket formed by Leu369, Leu371 and surrounding amino acids (Piala et al. 2014). Binding of $\mathrm{Cl}^{-}$to WNK1 precludes auto-phosphorylation and activation. Similarly, WNK4 is sensitive to $\mathrm{Cl}^{-}$and is inactivated by elevations in intracellular $\mathrm{Cl}^{-}$levels and by the mutation of Leu322 (which corresponds to Leu369 in WNK1) (Piala et al. 2014, Bazua-Valenti et al. 2015). Sensitivity to $\mathrm{Cl}^{-}$differs among WNKs, with WNK4 having the highest sensitivity (Terker et al. 2016). The KLHL3/ CUL3 complex binds and targets WNK1 and WNK4 for proteasomal degradation; disease-causing mutations impair this interaction (Ohta et al. 2013, Shibata et al. 2013b, Wakabayashi et al. 2013). In particular, PHAII mutations in the Kelch domain of KLHL3 and in an acidic domain of WNK4 both prevent KLHL3-WNK4 binding.

DCT cells express MR, and 11ßHSD2 is also present in the distal portion of DCTs (DCT2, which co-expresses NCC and $\mathrm{ENaC}$ ) (Campean et al. 2001). Aldosterone infusion increases NCC activity, and endogenous aldosterone production induced by diuretic treatment also leads to NCC upregulation (Velazquez et al. 1996, Kim et al. 1998). This is likely controlled at the post-translational level, since NCC induction is not accompanied by an increase in transcript abundance (Abdallah et al. 2001). Recent studies have indicated that the ubiquitin ligase Nedd4-2 and Ser/Thr kinase WNK1 mediate the effects of aldosterone on NCC. Although Nedd4-2 is a regulator of $\mathrm{ENaC}$ in principal cells, accumulating evidence suggests that it also regulates NCC (Arroyo et al. 2011, Ronzaud et al. 2013). Nedd4-2 co-immunoprecipitates with NCC and its deficiency in DCT cells results in NCC upregulation (Arroyo et al. 2011). Accordingly, total and phosphorylated NCC levels are increased in the kidney of tetracyclineinducible, nephron-specific Nedd4-2 knockout mice (Ronzaud et al. 2013). Unlike for ENaC, regulation of NCC by Nedd4-2 does not require the PY-like motif of NCC, suggesting that it may occur via an indirect mechanism.

A later study identified alternatively spliced exons embedded within a proline-rich region of WNK1 that contains PY motifs; these can be bound by Nedd4-2, which targets PY motif-containing WNK1 isoforms for proteasomal degradation (Fig. 3) (Roy et al. 2015). Because WNK1 is a potent activator of the SPAK/OSRNCC signaling cascade, these data suggest a mechanism whereby Nedd4-2 inhibits NCC. Moreover, aldosterone can regulate this process via the induction of Sgk1, which inhibits WNK1 degradation by inactivating Nedd4-2 and also induces WNK1 activity by phosphorylating its $\mathrm{N}$ terminus (Roy et al. 2015). Thus, the regulation of PY-containing WNK1 isoforms by Sgk1 and Nedd4-2 serves as the link between MR signaling and NCC induction in DCT cells (Fig. 3).

On the other hand, there is increasing evidence suggesting that NCC function in DCT cells is regulated independently of aldosterone. For example, AngII signaling regulates NCC via a mechanism that does not require aldosterone (van der Lubbe et al. 2013). In an effort to identify physiological mechanisms whereby AngII regulates NCC, we have identified phosphorylation of S433 in the Kelch (substrate-binding) domain of KLHL3 that turns off the function of KLHL3/CUL3 ubiquitin ligase (Shibata et al. 2014). S433 is shown to be repeatedly mutated in PHAII families, supporting its functional importance in substrate binding; in these cases, either KLHL3 ${ }^{5433 \mathrm{~N}}$ or KLHL3 ${ }^{5433 \mathrm{G}}$ substitution was sufficient to cause NCC activation, resulting in blood pressure elevation and hyperkalemia (Boyden et al. 2012, Louis-Dit-Picard et al. 2012).

A biochemical analysis revealed that KLHL3 phosphorylated at S433 (KLHL3 ${ }^{\text {S433-P) }}$ was incapable of substrate binding, resulting in impaired degradation and accumulation of WNK4. Phosphorylation at this site was regulated by protein kinase $\mathrm{C}$ (PKC) acting

Published by Bioscientifica Ltd. 


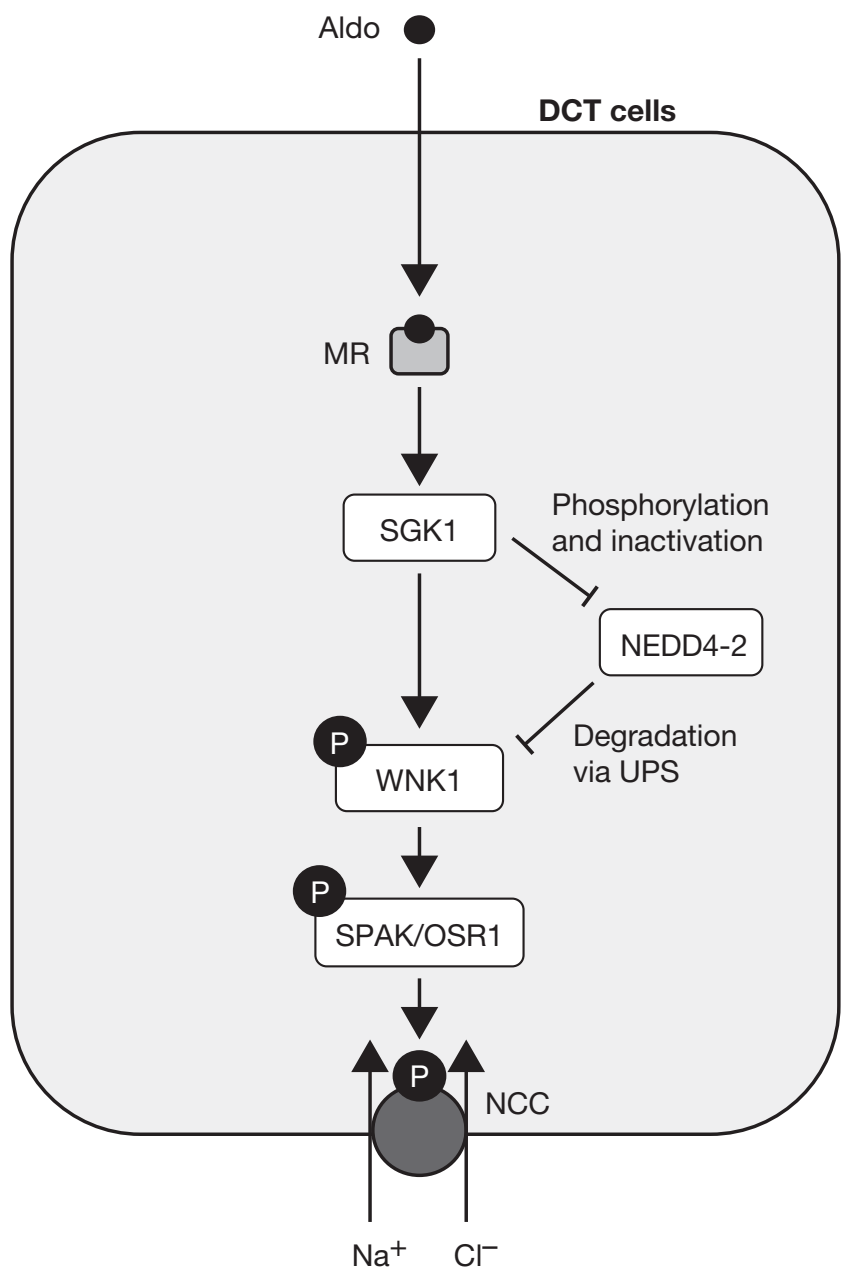

Figure 3

MR-dependent regulation of NCC in DCT cells. Aldosterone and MR increase serine/threonine kinase SGK1 abundance by regulating its transcription. SGK1 phosphorylates ubiquitin ligase Nedd4-2, which reduces its interaction with exons 11 and 12 of WNK1, preventing WNK1 degradation via the ubiquitin proteasome system (UPS). SGK1 then phosphorylates and increases WNK1 kinase activity. Active WNK1 in turn promotes SPAK and OSR 1 activation, which directly stimulates NCC by phosphorylation.

downstream of AngII (Shibata et al. 2014). The resultant decrease in KLHL3/CUL3 ubiquitin ligase activity leads to accumulation of WNKs, activating the SPAK/OSR1-NCC cascade. This pathway does not require aldosterone or MR signaling to induce NCC. Besides these mechanisms, there is also evidence that AngII modulates WNK function (SanCristobal et al. 2009). Of note, a recent study identified WNK4 sites that are phosphorylated downstream of AngII signaling (Castaneda-Bueno et al. 2017). Interestingly, AngII phosphorylation of WNK4 modulates WNK4 kinase activity by promoting autophosphorylation of S332 of the T-loop in the kinase catalytic domain.
Plasma $\mathrm{K}^{+}$levels also alter NCC activity independently of aldosterone. $\mathrm{K}+$ loading decreased NCC phosphorylation in DCTs even when plasma aldosterone was elevated (Sorensen et al. 2013, Rengarajan et al. 2014). In a model of PHAI lacking $\mathrm{ENaC} \alpha$ in the kidney, hyperkalemia was shown to determine NCC activity regardless of salt wasting and high plasma aldosterone (Perrier et al. 2015). Conversely, $\mathrm{K}^{+}$restriction increased NCC activity under aldosterone suppression (Castaneda-Bueno et al. 2014).

To evaluate the possible involvement of KLHL3/ CUL3-based ubiquitin ligase in low- $\mathrm{K}^{+}$-mediated NCC induction, we recently analyzed KLHL3 levels in mice on a low- $\mathrm{K}^{+}$diet (Ishizawa et al. 2016). Notably, we found that KLHL3 ${ }^{\text {s433-P }}$ levels were increased whereas total KLHL3 levels were decreased in the kidney by $\mathrm{K}^{+}$depletion. These data indicate that KLHL3/CUL3 ubiquitin ligase activity is suppressed by the net effect of KLHL3 ${ }^{\text {S433-P }}$ induction and decrease in the total levels. In fact, these changes were accompanied by the accumulation of the target substrate WNK4 and activation of the downstream kinases SPAK and OSR1, resulting in NCC phosphorylation and plasma membrane accumulation. Increased S433 phosphorylation was attributed to higher levels of active, phosphorylated PKC. This was the first demonstration of the involvement of KLHL3/CUL3 ubiquitin ligase in aldosteroneindependent, low- $\mathrm{K}^{+}$-mediated NCC induction (Fig. 4) (Ishizawa et al. 2016).

Besides the KLHL3/CUL3 complex, recent data indicate that the kinase activity of WNK is also regulated by changes in plasma $\mathrm{K}^{+}$levels (Fig. 4) (Terker et al. 2015b, Hadchouel et al. 2016). Hypokalemia is thought to induce hyperpolarization of DCT cell membrane voltage and potentiate $\mathrm{Cl}^{-}$efflux from the cells, resulting in reduced intracellular $\mathrm{Cl}^{-}$concentration. This, in turn, increases WNK kinase activity, activating NCC via SPAK/OSR1. The modulation of plasma $\mathrm{K}^{+}$levels altered NCC phosphorylation even in kidney-specific MR knockout mice, confirming that the proposed pathway is independent of MR signaling in these cells (Terker et al. 2015a). Thus, the increase in WNK levels by KLHL3 inactivation and WNK kinase activation induced by the change in intracellular $\mathrm{Cl}^{-}$levels synergistically regulate NCC (Fig. 4) (Terker et al. 2015b, Ishizawa et al. 2016). A recent study also reported that a $\mathrm{Cl}^{-}$- and SPAK/OSR1independent pathway activates NCC in hypokalemia (Penton et al. 2016).

NCC regulation through WNKs has also been implicated in hypertension associated with the use of calcineurin inhibitors (CNIs), which increase blood

Published by Bioscientifica Ltd. 


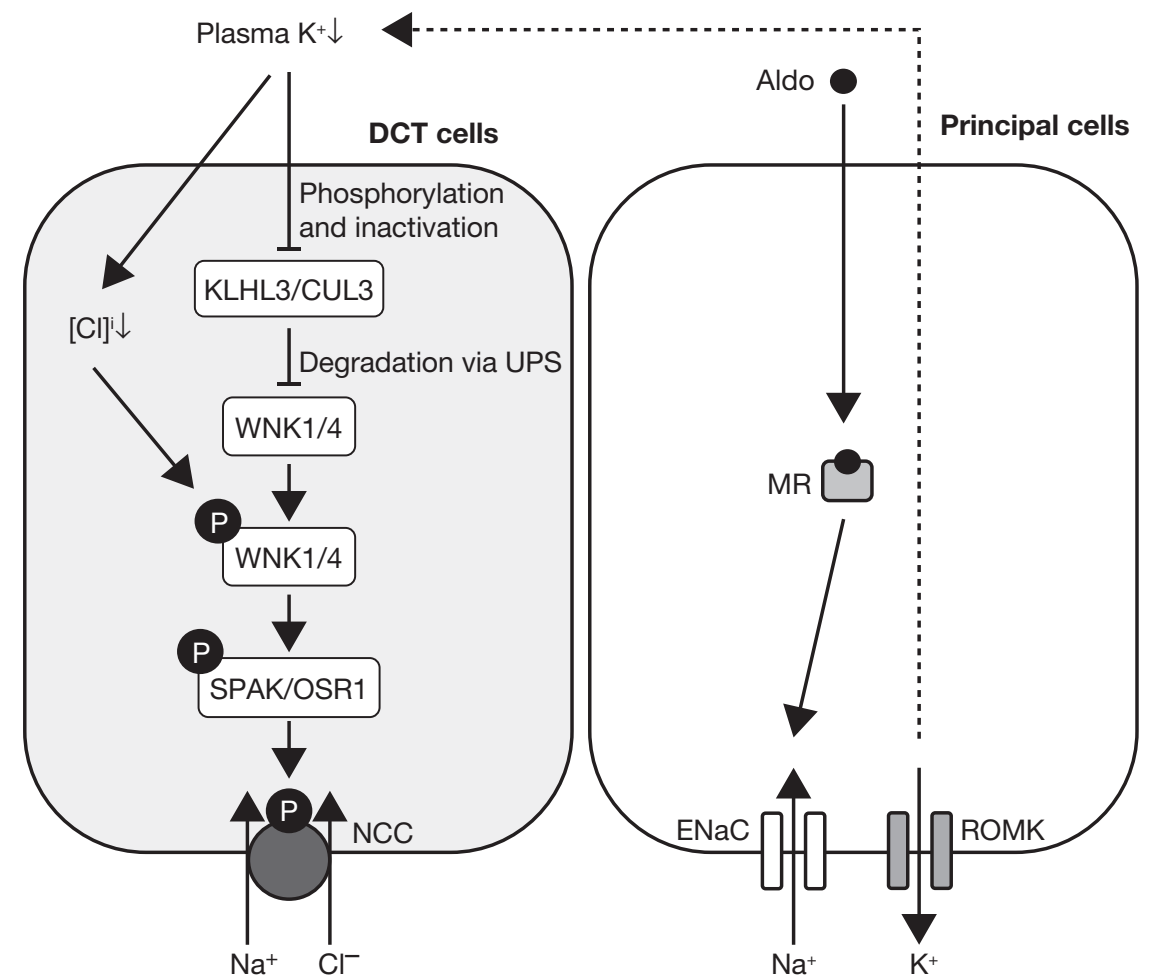

Figure 4

Hypokalemia-dependent regulation of NCC in DCT cells. The decrease in plasma $\mathrm{K}+$ levels by aldosterone stimulates the WNK-SPAK/OSR1-NCC cascade via two distinct mechanisms. Firstly, hypokalemia reduces the activity of ubiquitin ligase complex composed of KLHL3/CUL3 by $\$ 433$ phosphorylation and also by reducing total expression levels, thereby preventing WNK degradation via the ubiquitin proteasome system (UPS) and increasing WNK4 (and likely WNK1) levels. Secondly, hypokalemia reduces intracellular $\mathrm{Cl}$ - levels (shown as [Cl] $)$ by promoting $\mathrm{Cl}^{-}$efflux; this results in reduced $\mathrm{Cl}^{-}$ binding to WNK $1 / 4$ and increases the kinase activity. pressure through both vasoconstrictive and salt-retaining effects. Accumulating data indicate that the latter effect is mediated by NCC activity. Interestingly, the CNI tacrolimus (FK506) induced NCC phosphorylation in mice kidney (Hoorn et al. 2011) and caused salt-sensitive hypertension in wild-type mice but not in NCC knockout mice. Consistently, kidney transplant recipients treated with tacrolimus showed greater response to thiazide diuretics than those without. In the kidney, calcineurin colocalizes with NCC, and CNI administration associated with activation of the WNK/SPAK pathway, suggesting that WNK and SPAK mediate the NCC activation caused by CNIs. A recent study also showed that the $12-\mathrm{kDa}$ FK506 binding protein (FKBP12) is required for CNIinduced hypertension, since FKBP12 deletion in the renal nephron abolished NCC phosphorylation and blood pressure elevation in the kidney of mice treated with tacrolimus (Lazelle et al. 2016). How calcineurin interacts with SPAK and WNK remains to be determined.

In summary, the evidence to date indicates that two distinct ubiquitin ligases (i.e., Nedd4-2 and KLHL3/ CUL3) modulate NCC function, with two mechanisms converging on the regulation of WNK. However, the former is inactivated by aldosterone via Sgk1, whereas the latter is regulated by AngII and plasma $\mathrm{K}^{+}$levels. Whether KLHL3/CUL3 is regulated by aldosterone remains unknown.

\section{$\mathrm{NaCl}$ reabsorption and $\mathrm{K}^{+}$secretion in the distal nephron: integration of MR-dependent and -independent effects}

A key function of the renal distal nephron is to regulate $\mathrm{NaCl}$ reabsorption and $\mathrm{K}^{+}$secretion, both of which are stimulated by aldosterone. In the context of volume depletion, aldosterone increases $\mathrm{NaCl}$ reabsorption without increasing $\mathrm{K}^{+}$secretion, whereas in hyperkalemia, aldosterone maximizes $\mathrm{K}^{+}$secretion without altering $\mathrm{NaCl}$ reabsorption. These distinct effects of aldosterone are exerted by the coordinate actions of DCT cells, principal cells and intercalated cells.

Characterizing the pathways that regulate the activity of channels and transporters in the distal nephron has provided insights into the mechanisms that maintain the balance between $\mathrm{NaCl}$ reabsorption and $\mathrm{K}^{+}$secretion in high-aldosterone states. In the case of volume depletion or hyperkalemia, aldosterone production induces $\mathrm{ENaC}$ activation through MR and its downstream effectors, as described above. However, in the former instance, AngII promotes renal intercalated cell MR dephosphorylation, thereby promoting $\mathrm{Cl}^{-}$influx through these cells (Shibata et al. 2013a). In addition, AngII stimulates NCC by increasing the kinase activity of WNKs and inhibiting KLHL3/CUL3-based ubiquitin ligase, resulting in increased $\mathrm{NaCl}$ reabsorption in DCTs. These mechanisms

Published by Bioscientifica Ltd. 
act in concert to eliminate the lumen negativity driving $\mathrm{K}^{+}$secretion in the collecting duct, thereby suppressing urinary $\mathrm{K}^{+}$excretion. Conversely, hyperkalemia inhibits NCC and also blocks $\mathrm{Cl}^{-}$reabsorption in intercalated cells by increasing $\mathrm{MR}^{\mathrm{S} 843-\mathrm{P}}$, even when aldosterone levels are elevated. These changes favor $\mathrm{K}^{+}$secretion in exchange for electrogenic $\mathrm{Na}^{+}$reabsorption through $\mathrm{ENaC}$.

Besides regulating fluid volume, several lines of evidence support the importance of DCT and intercalated cells in renal $\mathrm{K}^{+}$handling. In PHAII, both high blood pressure and hyperkalemia can be corrected by thiazide treatment. Hyperkalemia in a mouse model of PHAII is also normalized by mating with NCC knockout mice (Lalioti et al. 2006). These data demonstrate that NCC activation contributes to the conservation of $\mathrm{K}^{+}$. In addition, in individuals with Pendred syndrome, thiazide treatment induces severe hypokalemia, highlighting the compensatory actions of pendrin and NCC in $\mathrm{K}^{+}$homeostasis. Furthermore, mathematical models of electrolyte handling in the collecting duct have demonstrated that the activation of intercalated cells along with principal cells results in maximal $\mathrm{NaCl}$ reabsorption while conserving $\mathrm{K}^{+}$(Weinstein 2002, Wall \& Weinstein 2013).

These mechanisms have implications for pathological conditions. For example, it is well known that the reduced $\mathrm{K}^{+}$intake increases blood pressure (Mente et al. 2014). Studies summarized in this article suggest that this inverse association is attributable to the regulation of NCC by hypokalemia/hyperkalemia via KLHL3/CUL3 ubiquitin ligase and WNK/SPAK signaling. In primary aldosteronism, high levels of circulating aldosterone are associated with decreased plasma $\mathrm{K}^{+}$concentration. The accompanying hypokalemia may aggravate high blood pressure by increasing NCC activity (Terker et al. 2015a) and also by modulating $\mathrm{MR}^{\mathrm{S} 843-\mathrm{P}}$ and pendrin expression in renal intercalated cells (Xu et al. 2017). Although these represent adaptive changes to prevent renal $\mathrm{K}^{+}$loss in hypokalemia, they result in increased $\mathrm{NaCl}$ reabsorption and hypertension.

\section{Conclusion}

This review summarized the current state of knowledge regarding mechanisms modulating the function of MR and its downstream targets in the distal nephron. Principal, intercalated and DCT cells are differentially regulated by the interplay of aldosterone, AngII and plasma $\mathrm{K}^{+}$, which controls the balance between $\mathrm{NaCl}$ reabsorption and $\mathrm{K}^{+}$secretion.

\section{Declaration of interest}

The author declares that there is no conflict of interest that could be perceived as prejudicing the impartiality of this review.

\section{Funding}

This work was supported in part by a Japan Society for the Promotion of Science KAKENHI grant (no. 15H04837) and by grants from Suzuki Memorial Foundation.

\section{References}

Abdallah JG, Schrier RW, Edelstein C, Jennings SD, Wyse B \& Ellison DH 2001 Loop diuretic infusion increases thiazide-sensitive $\mathrm{Na}(+) / \mathrm{Cl}(-)$ cotransporter abundance: role of aldosterone. Journal of the American Society of Nephrology 12 1335-1341.

Ackermann D, Gresko N, Carrel M, Loffing-Cueni D, Habermehl D, Gomez-Sanchez C, Rossier BC \& Loffing J 2010 In vivo nuclear translocation of mineralocorticoid and glucocorticoid receptors in rat kidney: differential effect of corticosteroids along the distal tubule. American Journal of Physiology: Renal Physiology 299 F1473-F1485. (doi:10.1152/ajprenal.00437.2010)

Alnemri ES, Maksymowych AB, Robertson NM \& Litwack G 1991 Overexpression and characterization of the human mineralocorticoid receptor. Journal of Biological Chemistry 266 18072-18081.

Alvarez de la Rosa D, Gimenez I, Forbush B \& Canessa CM 2006 SGK1 activates $\mathrm{Na}+-\mathrm{K}+-\mathrm{ATPase}$ in amphibian renal epithelial cells. American Journal of Physiology: Cell Physiology 290 C492-C498. (doi:10.1152/ ajpcell.00556.2004)

Arroyo JP, Lagnaz D, Ronzaud C, Vazquez N, Ko BS, Moddes L, RuffieuxDaidie D, Hausel P, Koesters R, Yang B, et al. 2011 Nedd4-2 modulates renal Na+-Cl-cotransporter via the aldosterone-SGK1-Nedd4-2 pathway. Journal of the American Society of Nephrology 22 1707-1719. (doi:10.1681/ASN.2011020132)

Bazua-Valenti S, Chavez-Canales M, Rojas-Vega L, Gonzalez-Rodriguez X, Vazquez N, Rodriguez-Gama A, Argaiz ER, Melo Z, Plata C, Ellison $\mathrm{DH}$, et al. 2015 The effect of WNK4 on the Na+-Cl-cotransporter is modulated by intracellular chloride. Journal of the American Society of Nephrology 26 1781-1786. (doi:10.1681/ASN.2014050470)

Bhalla V, Daidie D, Li H, Pao AC, LaGrange LP, Wang J, Vandewalle A, Stockand JD, Staub O \& Pearce D 2005 Serum- and glucocorticoidregulated kinase 1 regulates ubiquitin ligase neural precursor cellexpressed, developmentally down-regulated protein 4-2 by inducing interaction with 14-3-3. Molecular Endocrinology 19 3073-3084. (doi:10.1210/me.2005-0193)

Boulkroun S, Fernandes-Rosa FL \& Zennaro MC 2015 Molecular and cellular mechanisms of aldosterone producing adenoma development. Frontiers in Endocrinology 6 95. (doi:10.3389/ fendo.2015.00095)

Boyden LM, Choi M, Choate KA, Nelson-Williams CJ, Farhi A, Toka HR, Tikhonova IR, Bjornson R, Mane SM, Colussi G, et al. 2012 Mutations in kelch-like 3 and cullin 3 cause hypertension and electrolyte abnormalities. Nature 482 98-102. (doi:10.1038/nature10814)

Campean V, Kricke J, Ellison D, Luft FC \& Bachmann S 2001 Localization of thiazide-sensitive $\mathrm{Na}(+)-\mathrm{Cl}(-)$ cotransport and associated gene products in mouse DCT. American Journal of Physiology: Renal Physiology 281 F1028-F1035. (doi:10.1152/ajprenal.0148.2001)

Castaneda-Bueno M, Cervantes-Perez LG, Rojas-Vega L, Arroyo-Garza I, Vazquez N, Moreno E \& Gamba G 2014 Modulation of NCC activity by low and high $\mathrm{K}(+)$ intake: insights into the signaling pathways involved. American Journal of Physiology: Renal Physiology $\mathbf{3 0 6}$ F1507-F1519. (doi:10.1152/ajprenal.00255.2013) 
Castaneda-Bueno M, Arroyo JP, Zhang J, Puthumana J, Yarborough O 3rd, Shibata S, Rojas-Vega L, Gamba G, Rinehart J \& Lifton RP 2017 Phosphorylation by PKC and PKA regulate the kinase activity and downstream signaling of WNK4. PNAS 114 E879-E886. (doi:10.1073/ pnas.1620315114)

Chambrey R, Kurth I, Peti-Peterdi J, Houillier P, Purkerson JM, Leviel F, Hentschke M, Zdebik AA, Schwartz GJ, Hubner CA, et al. 2013 Renal intercalated cells are rather energized by a proton than a sodium pump. PNAS 110 7928-7933. (doi:10.1073/pnas.1221496110)

Choi JH, Banks AS, Estall JL, Kajimura S, Bostrom P, Laznik D, Ruas JL, Chalmers MJ, Kamenecka TM, Bluher M, et al. 2010 Anti-diabetic drugs inhibit obesity-linked phosphorylation of PPARgamma by Cdk5. Nature 466 451-456. (doi:10.1038/nature09291)

Faresse N, Vitagliano JJ \& Staub O 2012 Differential ubiquitylation of the mineralocorticoid receptor is regulated by phosphorylation. FASEB Journal 26 4373-4382. (doi:10.1096/fj.12-209924)

Fernandes-Rosa FL, Hubert EL, Fagart J, Tchitchek N, Gomes D, Jouanno E, Benecke A, Rafestin-Oblin ME, Jeunemaitre X, Antonini SR, et al. 2011 Mineralocorticoid receptor mutations differentially affect individual gene expression profiles in pseudohypoaldosteronism type 1. Journal of Clinical Endocrinology and Metabolism 96 E519-E527. (doi:10.1210/jc.2010-1486)

Finberg KE, Wagner CA, Stehberger PA, Geibel JP \& Lifton RP 2003 Molecular cloning and characterization of Atp6v1b1, the murine vacuolar H+-ATPase B1-subunit. Gene 318 25-34. (doi:10.1016/S03781119(03)00790-X)

Funder JW 2013 Angiotensin retains sodium by dephosphorylating mineralocorticoid receptors in renal intercalated cells. Cell Metabolism 18 609-610. (doi:10.1016/j.cmet.2013.10.010)

Funder JW, Pearce PT, Smith R \& Smith AI 1988 Mineralocorticoid action: target tissue specificity is enzyme, not receptor, mediated. Science $\mathbf{2 4 2}$ 583-585. (doi:10.1126/science.2845584)

Gaillard E, Bruck N, Brelivet Y, Bour G, Lalevee S, Bauer A, Poch O, Moras D \& Rochette-Egly C 2006 Phosphorylation by PKA potentiates retinoic acid receptor alpha activity by means of increasing interaction with and phosphorylation by cyclin H/cdk7. PNAS 103 9548-9553. (doi:10.1073/pnas.0509717103)

Galigniana MD 1998 Native rat kidney mineralocorticoid receptor is a phosphoprotein whose transformation to a DNA-binding form is induced by phosphatases. Biochemical Journal 333 555-563. (doi:10.1042/bj3330555)

Garg LC \& Narang N 1988 Effects of aldosterone on NEM-sensitive ATPase in rabbit nephron segments. Kidney International 34 13-17. (doi:10.1038/ki.1988.139)

Gueutin V, Vallet M, Jayat M, Peti-Peterdi J, Corniere N, Leviel F, Sohet F, Wagner CA, Eladari D \& Chambrey R 2013 Renal beta-intercalated cells maintain body fluid and electrolyte balance. Journal of Clinical Investigation 123 4219-4231. (doi:10.1172/JCI63492)

Hadchouel J, Ellison DH \& Gamba G 2016 Regulation of renal electrolyte transport by WNK and SPAK-OSR1 kinases. Annual Review of Physiology 78 367-389. (doi:10.1146/annurev-physiol-021115-105431)

Hayhurst RA \& O'Neil RG 1988 Time-dependent actions of aldosterone and amiloride on Na+-K+-ATPase of cortical collecting duct. American Journal of Physiology 254 F689-F696.

Hebert SC, Desir G, Giebisch G \& Wang W 2005 Molecular diversity and regulation of renal potassium channels. Physiological Reviews 85 319-371. (doi:10.1152/physrev.00051.2003)

Hoorn EJ, Walsh SB, McCormick JA, Furstenberg A, Yang CL, Roeschel T, Paliege A, Howie AJ, Conley J, Bachmann S, et al. 2011 The calcineurin inhibitor tacrolimus activates the renal sodium chloride cotransporter to cause hypertension. Nature Medicine 17 1304-1309. (doi:10.1038/nm.2497)

Hou J, Rajagopal M \& Yu AS 2013 Claudins and the kidney. Annual Review of Physiology 75 479-501. (doi:10.1146/annurevphysiol-030212-183705)
Ishizawa K, Xu N, Loffing J, Lifton RP, Fujita T, Uchida S \& Shibata S 2016 Potassium depletion stimulates $\mathrm{Na}-\mathrm{Cl}$ cotransporter via phosphorylation and inactivation of the ubiquitin ligase Kelch-like 3. Biochemical and Biophysical Research Communications 480 745-751. (doi:10.1016/j.bbrc.2016.10.127)

Izumi Y, Hori K, Nakayama Y, Kimura M, Hasuike Y, Nanami M, Kohda Y, Otaki Y, Kuragano T, Obinata M, et al. 2011 Aldosterone requires vasopressin $\mathrm{V} 1 \mathrm{a}$ receptors on intercalated cells to mediate acid-base homeostasis. Journal of the American Society of Nephrology 22 673-680. (doi:10.1681/ASN.2010050468)

Jacques T, Picard N, Miller RL, Riemondy KA, Houillier P, Sohet F, Ramakrishnan SK, Busst CJ, Jayat M, Corniere N, et al. 2013 Overexpression of pendrin in intercalated cells produces chloridesensitive hypertension. Journal of the American Society of Nephrology $\mathbf{2 4}$ 1104-1113. (doi:10.1681/ASN.2012080787)

Kahle KT, Wilson FH, Leng Q, Lalioti MD, O'Connell AD, Dong K, Rapson AK, MacGregor GG, Giebisch G, Hebert SC, et al. 2003 WNK4 regulates the balance between renal $\mathrm{NaCl}$ reabsorption and $\mathrm{K}+$ secretion. Nature Genetics 35 372-376. (doi:10.1038/ng1271)

Kamynina E \& Staub O 2002 Concerted action of ENaC, Nedd4-2, and Sgk1 in transepithelial $\mathrm{Na}(+)$ transport. American Journal of Physiology: Renal Physiology 283 F377-F387. (doi:10.1152/ajprenal.00143.2002)

Kandasamy N, Fugazzola L, Evans M, Chatterjee K \& Karet F 2011 Life-threatening metabolic alkalosis in Pendred syndrome. European Journal of Endocrinology 165 167-170. (doi:10.1530/EJE-11-0101)

Karet FE, Finberg KE, Nelson RD, Nayir A, Mocan H, Sanjad SA, Rodriguez-Soriano J, Santos F, Cremers CW, Di Pietro A, et al. 1999 Mutations in the gene encoding B1 subunit of H+-ATPase cause renal tubular acidosis with sensorineural deafness. Nature Genetics 21 84-90. (doi:10.1038/5022)

Kim GH, Masilamani S, Turner R, Mitchell C, Wade JB \& Knepper MA 1998 The thiazide-sensitive $\mathrm{Na}-\mathrm{Cl}$ cotransporter is an aldosterone-induced protein. PNAS 95 14552-14557. (doi:10.1073/ pnas.95.24.14552)

Kino T, Jaffe H, Amin ND, Chakrabarti M, Zheng YL, Chrousos GP \& Pant HC 2010 Cyclin-dependent kinase 5 modulates the transcriptional activity of the mineralocorticoid receptor and regulates expression of brain-derived neurotrophic factor. Molecular Endocrinology 24 941-952. (doi:10.1210/me.2009-0395)

Lalioti MD, Zhang J, Volkman HM, Kahle KT, Hoffmann KE, Toka HR, Nelson-Williams C, Ellison DH, Flavell R, Booth CJ, et al. 2006 Wnk4 controls blood pressure and potassium homeostasis via regulation of mass and activity of the distal convoluted tubule. Nature Genetics $\mathbf{3 8}$ 1124-1132. (doi:10.1038/ng1877)

Lang F \& Pearce D 2016 Regulation of the epithelial Na+ channel by the mTORC2/SGK1 pathway. Nephrology Dialysis Transplantation 31 200-205.

Lazelle RA, McCully BH, Terker AS, Himmerkus N, Blankenstein KI, Mutig K, Bleich M, Bachmann S, Yang CL \& Ellison DH 2016 Renal deletion of $12 \mathrm{kDa}$ FK506-binding protein attenuates tacrolimusinduced hypertension. Journal of the American Society of Nephrology 27 1456-1464. (doi:10.1681/ASN.2015040466)

Leviel F, Hubner CA, Houillier P, Morla L, El Moghrabi S, Brideau G, Hassan H, Parker MD, Kurth I, Kougioumtzes A, et al. 2010 The $\mathrm{Na}$-dependent chloride-bicarbonate exchanger SLC4A8 mediates an electroneutral $\mathrm{Na}+$ reabsorption process in the renal cortical collecting ducts of mice. Journal of Clinical Investigation 120 1627-1635. (doi:10.1172/JCI40145)

Lifton RP, Gharavi AG \& Geller DS 2001 Molecular mechanisms of human hypertension. Cell 104 545-556. (doi:10.1016/S00928674(01)00241-0)

Lin DH, Sterling H, Yang B, Hebert SC, Giebisch G \& Wang WH 2004 Protein tyrosine kinase is expressed and regulates ROMK1 location in the cortical collecting duct. American Journal of Physiology: Renal Physiology 286 F881-F892. (doi:10.1152/ajprenal.00301.2003) http://joe.endocrinology-journals.org

DOI: 10.1530/JOE-16-0669
๑ 2017 Society for Endocrinology Printed in Great Britain 
Lin DH, Yue P, Yarborough O 3rd, Scholl UI, Giebisch G, Lifton RP, Rinehart J \& Wang WH 2015 Src-family protein tyrosine kinase phosphorylates WNK4 and modulates its inhibitory effect on KCNJ1 (ROMK). PNAS 112 4495-4500. (doi:10.1073/pnas.1503437112)

Louis-Dit-Picard H, Barc J, Trujillano D, Miserey-Lenkei S, Bouatia-Naji N, Pylypenko O, Beaurain G, Bonnefond A, Sand O, Simian C, et al. 2012 KLHL3 mutations cause familial hyperkalemic hypertension by impairing ion transport in the distal nephron. Nature Genetics 44 456-460, S451-S453. (doi:10.1038/ng.2218)

Mente A, O’Donnell MJ, Rangarajan S, McQueen MJ, Poirier P, Wielgosz A, Morrison H, Li W, Wang X, Di C, et al. 2014 Association of urinary sodium and potassium excretion with blood pressure. New England Journal of Medicine 371 601-611. (doi:10.1056/ NEJMoa1311989)

Mick VE, Itani OA, Loftus RW, Husted RF, Schmidt TJ \& Thomas CP 2001 The alpha-subunit of the epithelial sodium channel is an aldosteroneinduced transcript in mammalian collecting ducts, and this transcriptional response is mediated via distinct cis-elements in the 5'-flanking region of the gene. Molecular Endocrinology 15 575-588. (doi:10.1210/me.15.4.575)

Mohebbi N, Perna A, van der Wijst J, Becker HM, Capasso G \& Wagner CA 2013 Regulation of two renal chloride transporters, AE1 and pendrin, by electrolytes and aldosterone. PLoS One $\mathbf{8}$ e55286. (doi:10.1371/journal.pone.0055286)

Narikiyo T, Kitamura K, Adachi M, Miyoshi T, Iwashita K, Shiraishi N, Nonoguchi H, Chen LM, Chai KX, Chao J, et al. 2002 Regulation of prostasin by aldosterone in the kidney. Journal of Clinical Investigation 109 401-408. (doi:10.1172/JCI0213229)

Ohta A, Schumacher FR, Mehellou Y, Johnson C, Knebel A, Macartney TJ, Wood NT, Alessi DR \& Kurz T 2013 The CUL3-KLHL3 E3 ligase complex mutated in Gordon's hypertension syndrome interacts with and ubiquitylates WNK isoforms: disease-causing mutations in KLHL3 and WNK4 disrupt interaction. Biochemical Journal 451 111-122. (doi:10.1042/BJ20121903)

Ortlund EA, Bridgham JT, Redinbo MR \& Thornton JW 2007 Crystal structure of an ancient protein: evolution by conformational epistasis. Science 317 1544-1548. (doi:10.1126/science.1142819)

Pearce D, Soundararajan R, Trimpert C, Kashlan OB, Deen PM \& Kohan DE 2015 Collecting duct principal cell transport processes and their regulation. Clinical Journal of the American Society of Nephrology $\mathbf{1 0}$ 135-146. (doi:10.2215/CJN.05760513)

Pech V, Kim YH, Weinstein AM, Everett LA, Pham TD \& Wall SM 2007 Angiotensin II increases chloride absorption in the cortical collecting duct in mice through a pendrin-dependent mechanism. American Journal of Physiology: Renal Physiology 292 F914-F920. (doi:10.1152/ ajprenal.00361.2006)

Pela I, Bigozzi M \& Bianchi B 2008 Profound hypokalemia and hypochloremic metabolic alkalosis during thiazide therapy in a child with Pendred syndrome. Clinical Nephrology 69 450-453. (doi:10.5414/CNP69450)

Penton D, Czogalla J, Wengi A, Himmerkus N, Loffing-Cueni D, Carrel M, Rajaram RD, Staub O, Bleich M, Schweda F, et al. 2016 Extracellular $\mathrm{K}+$ rapidly controls $\mathrm{NaCl}$ cotransporter phosphorylation in the native distal convoluted tubule by $\mathrm{Cl}$--dependent and independent mechanisms. Journal of Physiology 594 6319-6331. (doi:10.1113/ JP272504)

Perrier R, Boscardin E, Malsure S, Sergi C, Maillard MP, Loffing J, Loffing DC, Sorensen MV, Koesters R, Rossier BC, et al. 2015 Severe salt-losing syndrome and hyperkalemia induced by adult nephron-specific knockout of the epithelial sodium channel alpha-subunit. Journal of the American Society of Nephrology 27 2309-2318. (doi:10.1681/ ASN.2015020154)

Piala AT, Moon TM, Akella R, He H, Cobb MH \& Goldsmith EJ 2014 Chloride sensing by WNK1 involves inhibition of autophosphorylation. Science Signaling 7 ra41. (doi:10.1126/ scisignal.2005050)
Rengarajan S, Lee DH, Oh YT, Delpire E, Youn JH \& McDonough AA 2014 Increasing plasma $[\mathrm{K}+]$ by intravenous potassium infusion reduces NCC phosphorylation and drives kaliuresis and natriuresis. American Journal of Physiology: Renal Physiology 306 F1059-F1068. (doi:10.1152/ ajprenal.00015.2014)

Rinehart J, Maksimova YD, Tanis JE, Stone KL, Hodson CA, Zhang J, Risinger M, Pan W, Wu D, Colangelo CM, et al. 2009 Sites of regulated phosphorylation that control K-Cl cotransporter activity. Cell 138 525-536. (doi:10.1016/j.cell.2009.05.031)

Ronzaud C, Loffing-Cueni D, Hausel P, Debonneville A, Malsure SR, Fowler-Jaeger N, Boase NA, Perrier R, Maillard M, Yang B, et al. 2013 Renal tubular NEDD4-2 deficiency causes NCC-mediated saltdependent hypertension. Journal of Clinical Investigation 123 657-665.

Roy A, Al-Qusairi L, Donnelly BF, Ronzaud C, Marciszyn AL, Gong F, Chang YP, Butterworth MB, Pastor-Soler NM, Hallows KR, et al. 2015 Alternatively spliced proline-rich cassettes link WNK1 to aldosterone action. Journal of Clinical Investigation 125 3433-3448. (doi:10.1172/ JCI75245)

Royaux IE, Wall SM, Karniski LP, Everett LA, Suzuki K, Knepper MA \& Green ED 2001 Pendrin, encoded by the Pendred syndrome gene, resides in the apical region of renal intercalated cells and mediates bicarbonate secretion. PNAS 98 4221-4226. (doi:10.1073/ pnas.071516798)

San-Cristobal P, Pacheco-Alvarez D, Richardson C, Ring AM, Vazquez N, Rafiqi FH, Chari D, Kahle KT, Leng Q, Bobadilla NA, et al. 2009 Angiotensin II signaling increases activity of the renal $\mathrm{Na}-\mathrm{Cl}$ cotransporter through a WNK4-SPAK-dependent pathway. PNAS 106 4384-4389. (doi:10.1073/pnas.0813238106)

Sanei-Moghaddam A, Wilson T, Kumar S \& Gray R 2011 An unfortunate case of Pendred syndrome. Journal of Laryngology and Otology $\mathbf{1 2 5}$ 965-967. (doi:10.1017/S0022215111001630)

Setiawan I, Henke G, Feng Y, Bohmer C, Vasilets LA, Schwarz W \& Lang F 2002 Stimulation of Xenopus oocyte $\mathrm{Na}(+), \mathrm{K}(+)$ ATPase by the serum and glucocorticoid-dependent kinase sgk1. Pflügers Archiv $\mathbf{4 4 4}$ 426-431. (doi:10.1007/s00424-002-0823-z)

Shibata S, Rinehart J, Zhang J, Moeckel G, Castaneda-Bueno M, Stiegler AL, Boggon TJ, Gamba G \& Lifton RP 2013a Mineralocorticoid receptor phosphorylation regulates ligand binding and renal response to volume depletion and hyperkalemia. Cell Metabolism 18 660-671. (doi:10.1016/j.cmet.2013.10.005)

Shibata S, Zhang J, Puthumana J, Stone KL \& Lifton RP $2013 b$ Kelch-like 3 and Cullin 3 regulate electrolyte homeostasis via ubiquitination and degradation of WNK4. PNAS 110 7838-7843. (doi:10.1073/ pnas.1304592110)

Shibata S, Arroyo JP, Castaneda-Bueno M, Puthumana J, Zhang J, Uchida S, Stone KL, Lam TT \& Lifton RP 2014 Angiotensin II signaling via protein kinase C phosphorylates Kelch-like 3, preventing WNK4 degradation. PNAS 111 15556-15561. (doi:10.1073/pnas.1418342111)

Shimkets RA, Warnock DG, Bositis CM, Nelson-Williams C, Hansson JH, Schambelan M, Gill JR, Jr., Ulick S, Milora RV, Findling JW, et al. 1994 Liddle's syndrome: heritable human hypertension caused by mutations in the beta subunit of the epithelial sodium channel. Cell 79 407-414. (doi:10.1016/0092-8674(94)90250-X)

Sinning A, Radionov N, Trepiccione F, Lopez-Cayuqueo KI, Jayat M, Baron S, Corniere N, Alexander RT, Hadchouel J, Eladari D, et al. 2016 Double knockout of the $\mathrm{Na}+$-driven $\mathrm{Cl}-$ /HCO3-exchanger and $\mathrm{Na}+/ \mathrm{Cl}$ - cotransporter induces hypokalemia and volume depletion. Journal of the American Society of Nephrology 28 130-139. (doi:10.1681/ ASN.2015070734)

Soleimani M, Barone S, Xu J, Shull GE, Siddiqui F, Zahedi K \& Amlal H 2012 Double knockout of pendrin and $\mathrm{Na}-\mathrm{Cl}$ cotransporter (NCC) causes severe salt wasting, volume depletion, and renal failure. PNAS 109 13368-13373. (doi:10.1073/pnas.1202671109)

Sorensen MV, Grossmann S, Roesinger M, Gresko N, Todkar AP, Barmettler G, Ziegler U, Odermatt A, Loffing-Cueni D \& Loffing J 2013 Rapid dephosphorylation of the renal sodium chloride 
cotransporter in response to oral potassium intake in mice. Kidney International 83 811-824. (doi:10.1038/ki.2013.14)

Spat A \& Hunyady L 2004 Control of aldosterone secretion: a model for convergence in cellular signaling pathways. Physiological Reviews 84 489-539. (doi:10.1152/physrev.00030.2003)

Staub O, Dho S, Henry P, Correa J, Ishikawa T, McGlade J \& Rotin D 1996 WW domains of Nedd4 bind to the proline-rich PY motifs in the epithelial $\mathrm{Na}+$ channel deleted in Liddle's syndrome. EMBO Journal 15 2371-2380.

Svenningsen P, Bistrup C, Friis UG, Bertog M, Haerteis S, Krueger B, Stubbe J, Jensen ON, Thiesson HC, Uhrenholt TR, et al. 2009 Plasmin in nephrotic urine activates the epithelial sodium channel. Journal of the American Society of Nephrology 20 299-310. (doi:10.1681/ ASN.2008040364)

Svenningsen P, Andersen H, Nielsen LH \& Jensen BL 2015 Urinary serine proteases and activation of ENaC in kidney - implications for physiological renal salt handling and hypertensive disorders with albuminuria. Pflügers Archiv 467 531-542.

Terada Y \& Knepper MA 1990 Thiazide-sensitive $\mathrm{NaCl}$ absorption in rat cortical collecting duct. American Journal of Physiology 259 F519-F528.

Terker AS, Yarbrough B, Ferdaus MZ, Lazelle RA, Erspamer KJ, Meermeier NP, Park HJ, McCormick JA, Yang CL \& Ellison DH $2015 a$ Direct and indirect mineralocorticoid effects determine distal salt transport. Journal of the American Society of Nephrology 27 2436-2445. (doi:10.1681/ASN.2015070815)

Terker AS, Zhang C, McCormick JA, Lazelle RA, Zhang C, Meermeier NP, Siler DA, Park HJ, Fu Y, Cohen DM, et al. 2015b Potassium modulates electrolyte balance and blood pressure through effects on distal cell voltage and chloride. Cell Metabolism 21 39-50. (doi:10.1016/j. cmet.2014.12.006)

Terker AS, Zhang C, Erspamer KJ, Gamba G, Yang CL \& Ellison DH 2016 Unique chloride-sensing properties of WNK4 permit the distal nephron to modulate potassium homeostasis. Kidney International 89 127-134. (doi:10.1038/ki.2015.289)

Tsuchiya K, Giebisch G \& Welling PA 1996 Aldosterone-dependent regulation of Na-K-ATPase subunit mRNA in the rat CCD: competitive PCR analysis. American Journal of Physiology 271 F7-F15.

Vallet V, Chraibi A, Gaeggeler HP, Horisberger JD \& Rossier BC 1997 An epithelial serine protease activates the amiloride-sensitive sodium channel. Nature 389 607-610. (doi:10.1038/39329)

van der Lubbe N, Zietse R \& Hoorn EJ 2013 Effects of angiotensin II on kinase-mediated sodium and potassium transport in the distal nephron. Current Opinion in Nephrology and Hypertension 22 120-126. (doi:10.1097/MNH.0b013e32835b6551)

Velazquez H, Bartiss A, Bernstein P \& Ellison DH 1996 Adrenal steroids stimulate thiazide-sensitive $\mathrm{NaCl}$ transport by rat renal distal tubules. American Journal of Physiology 270 F211-F219.

Verlander JW, Hassell KA, Royaux IE, Glapion DM, Wang ME, Everett LA, Green ED \& Wall SM 2003 Deoxycorticosterone upregulates PDS (Slc26a4) in mouse kidney: role of pendrin in mineralocorticoidinduced hypertension. Hypertension 42 356-362. (doi:10.1161/01. HYP.0000088321.67254.B7)
Verrey F, Loffing J, Zecevic M, Heitzmann D \& Staub O 2003a SGK1: aldosterone-induced relay of $\mathrm{Na}+$ transport regulation in distal kidney nephron cells. Cellular Physiology and Biochemistry 13 21-28. (doi:10.1159/000070246)

Verrey F, Summa V, Heitzmann D, Mordasini D, Vandewalle A, Feraille E \& Zecevic M 2003b Short-term aldosterone action on $\mathrm{Na}, \mathrm{K}-\mathrm{ATP}$ ase surface expression: role of aldosterone-induced SGK1? Annals of the New York Academy of Sciences 986 554-561. (doi:10.1111/j.1749-6632.2003.tb07253.x)

Vitari AC, Deak M, Morrice NA \& Alessi DR 2005 The WNK1 and WNK4 protein kinases that are mutated in Gordon's hypertension syndrome phosphorylate and activate SPAK and OSR1 protein kinases. Biochemical Journal 391 17-24. (doi:10.1042/BJ20051180)

Wakabayashi M, Mori T, Isobe K, Sohara E, Susa K, Araki Y, Chiga M, Kikuchi E, Nomura N, Mori Y, et al. 2013 Impaired KLHL3-mediated ubiquitination of WNK4 causes human hypertension. Cell Reports $\mathbf{3}$ 858-868. (doi:10.1016/j.celrep.2013.02.024)

Wall SM \& Weinstein AM 2013 Cortical distal nephron Cl(-) transport in volume homeostasis and blood pressure regulation. American Journal of Physiology: Renal Physiology 305 F427-F438. (doi:10.1152/ ajpcell.00034.2013)

Wall SM, Kim YH, Stanley L, Glapion DM, Everett LA, Green ED \& Verlander JW $2004 \mathrm{NaCl}$ restriction upregulates renal Slc26a4 through subcellular redistribution: role in $\mathrm{Cl}-$ conservation. Hypertension 44 982-987. (doi:10.1161/01.hyp.0000145863.96091.89)

Wang YB, Leroy V, Maunsbach AB, Doucet A, Hasler U, Dizin E, Ernandez T, de Seigneux S, Martin PY \& Feraille E 2014 Sodium transport is modulated by p38 kinase-dependent cross-talk between ENaC and $\mathrm{Na}, \mathrm{K}-\mathrm{ATPa}$ e in collecting duct principal cells. Journal of the American Society of Nephrology 25 250-259. (doi:10.1681/ASN.2013040429)

Weinstein AM 2002 A mathematical model of rat collecting duct. III. Paradigms for distal acidification defects. American Journal of Physiology: Renal Physiology 283 F1267-F1280. (doi:10.1152/ ajpcell.00609.2001)

Welling PA 2013 Regulation of renal potassium secretion: molecular mechanisms. Seminars in Nephrology 33 215-228. (doi:10.1016/j. semnephrol.2013.04.002)

Wilson FH, Disse-Nicodeme S, Choate KA, Ishikawa K, Nelson-Williams C, Desitter I, Gunel M, Milford DV, Lipkin GW, Achard JM, et al. 2001 Human hypertension caused by mutations in WNK kinases. Science 293 1107-1112. (doi:10.1126/science.1062844)

Xu N, Hirohama D, Ishizawa K, Chang WX, Shimosawa T, Fujita T, Uchida S \& Shibata S 2017 Hypokalemia and pendrin induction by aldosterone. Hypertension [in press]. (doi:10.1161/ HYPERTENSIONAHA.116.08519)

Yoo D, Kim BY, Campo C, Nance L, King A, Maouyo D \& Welling PA 2003 Cell surface expression of the ROMK (Kir 1.1) channel is regulated by the aldosterone-induced kinase, SGK-1, and protein kinase A. Journal of Biological Chemistry 278 23066-23075. (doi:10.1074/jbc. M212301200)

Zhang W, Xia X, Reisenauer MR, Rieg T, Lang F, Kuhl D, Vallon V \& Kone BC 2007 Aldosterone-induced Sgk1 relieves Dot1a-Af9-mediated transcriptional repression of epithelial $\mathrm{Na}+$ channel alpha. Journal of Clinical Investigation 117 773-783. (doi:10.1172/JCI29850)

Received in final form 22 March 2017

Accepted 24 March 2017

Accepted Preprint published online 24 March 2017 http://joe.endocrinology-journals.org

DOI: 10.1530/JOE-16-0669
๑) 2017 Society for Endocrinology Printed in Great Britain
Published by Bioscientifica Ltd. 